\title{
Comprehensive analysis of the key epidemiological parameters to evaluate the impact of BCG vaccination on COVID-19 pandemic
}

\author{
Niloy R. Datta ${ }^{1}$ and Sneha Datta ${ }^{2}$ \\ 1 Senior Consultant, Formerly at Kantonsspital Aarau, Aarau, Switzerland, 2 Independent \\ Researcher, London, United Kinngdom UK.
}

\section{Address for correspondence:}

Prof. Niloy Ranjan Datta,

Hübeliackerweg 2, Suhr, Aargau, CH 5034, Switzerland,

email: nrdatta@yahoo.com

Tel: +41-762922590

Short title: Impact of BCG vaccination on COVID-19

Data Availability Statement : Data used is available in the Supplementary Table 1. The data have been retrieved from the public domains of the websites as mentioned in the text. All these data are freely available online.

Funding: The authors received no funding for this work.

Conflict of interest: The authors declare no conflict of interest. 


\section{Abstract}

Globally, the heterogenous coronavirus disease 2019 (COVID-19) case fatality rate (CFR) could be influenced by various epidemiological parameters. Identifying these could help formulate effective public health strategies. Incidence and mortality of COVID-19 for each of the 220 countries as on July 30, 2020 were evaluated against key epidemiological variables, namely - BCG vaccination (ongoing vs. discontinued/never undertaken), \%population aged $\geq 65$ years, incidences of ischemic heart disease (IHD), hypertensive heart disease (HHD), cancer, malaria, and diabetes; human development index (HDI) and population density. These were retrieved from the public domains of WHO, UN, World Bank and published reports. The COVID-19 CFRs ranged between $0.0 \%$ and $28.3 \%$ (mean \pm SD: $3.05 \% \pm 3.48$ ). The influence of the individual epidemiological parameters on CFR were evaluated through the event rate estimations. A significantly lower event rate was observed in countries with ongoing BCG vaccination program (ER: with vs without ongoing BCG vaccination: 0.020 vs 0.034 , $p<0.001)$. The type of BCG strains used also influenced the ER; this being $0.018,0.031$ and 0.019 for early, late and mixed strains respectively $(p=0.008)$. The epidemiological variables significantly associated with higher COVID-19 event rate were countries with higher \%population aged $\geq 65$ years $(p<0.001)$, greater incidence of IHD $(p<0.001)$ and cancer $(p=0.003)$ and better HDI $(p=0.003)$. Incidences of malaria, HHD and diabetes along with population density had no significant impact on COVID-19 CFR. Further, BCG vaccination significantly lowered the COVID-19 ER in each of the highrisk population subgroups - countries with $>7.1 \%$ population aged $\geq 65$ years $(p=0.008),>0.737 \mathrm{HDI}$ $(p=0.001), I H D>1171 / 10^{5}$ population $(p=0.004)$ and cancer incidence $>15726(p<0.001)$. The results supports BCG induced "trained immunity" leading to heterologous immunoprotection against COVID-19. Thus BCG vaccination with early strains could provide a cost-effective prophylaxis, especially in high-risk individuals and bridge the gap till an effective vaccine against SARS-CoV-2 is freely available globally. 


\section{Introduction}

As the global community eagerly waits for a successful vaccine against severe acute respiratory sickness coronavirus 2 (SARS-CoV-2) responsible for the ongoing pandemic of coronavirus disease 2019 (COVID-19), the morbidity and mortality continues to rise unabated. While some countries have seen off the passing of the first wave of COVID-19, others continue to face the onslaught with a rising trend. Further, the danger of a second wave still looms large over the regions that have contained the first wave of COVID-19 with varying degrees of morbidity and mortality.

A glance at the world-wide pattern of case fatality of COVID-19 reveals a gross heterogeneity in its distribution. This could be attributed to a complex interaction of host factors that could include the virulence of the strains of SARS-CoV-2, appropriate enforcement of containment measures, screening and contact tracing, population density, availability of adequate medical care, inherent susceptibility of the population, associated comorbid conditions, socioeconomic status and others [1-9]. Presently, although there are some indications of the individual factors to impact the COVID19 mortality, a comprehensive evaluation of the relevant epidemiological variables towards the heterogenous case fatality is needed to identify parameter/s that might help to alleviate the mortality and consider active interventions in high-risk population.

Thus, a comprehensive analysis has been carried out by estimating the event rates to evaluate the influence of key epidemiological factors on the case fatality rate (CFR) of COVID-19. As the policy of subjecting the inhabitants of a country to routine BCG vaccination is the variable in the 220 countries evaluated, the purpose of this study is to evaluate the likely impact of BCG vaccination on the heterogenous COVID-19 CFR. Thus the effect of BCG vaccination and the strains used have been studied to specifically estimate its impact on each of the high-risk populations as evident from 
this study. This might assist the national health agencies to formulate country specific public health guidelines to mitigate the COVID-19 case fatality, especially in high-risk inhabitants.

\section{Methods}

\section{Databases used}

The estimates of total cases, total deaths, cases/million and deaths/million due to COVID-19 were extracted for each country and their dependent territories as listed in the WHO [10] and Worldometer [11] websites as on July 7, 2020 (Fig.1). COVID-19 CFR for each country was computed using the total cases and deaths listed as (total deaths/total cases) $\times 100$.

The epidemiological parameters were retrieved from the public domains of WHO, UN, World Bank, BCG World Atlas and published reports for each listed countries (Fig.1). These included - \%BCG vaccination (2018) [12, 13], \%population aged $\geq 65$ years (2018) [14], incidences of ischemic heart disease (IHD) (2015) [15], hypertensive heart disease (HHD) (2015) [15], cancer (2020) [16], malaria (2018) [17] and diabetes [18]; human development index (HDI) (2019) [19] and population density (2018) [20]. In all cases, the latest values listed in the above public domains were considered.

Based on the national BCG immunization program, the countries were grouped as, either (a) countries where the BCG vaccination is currently not ongoing or those where is had been discontinued or in those where its recommended selectively for the high-risk groups (e.g. health workers) and (b) countries with ongoing BCG program for all its inhabitants.

It was also evident that BCG strains used for their immunization program varied in these countries. Broadly these countries are classified as using early (BCG Russia, Brazil, Japan, Sweden, Birkhaug) or late BCG strains (BCG Prague, China, Glaxo, Denmark, Tice, Frappier, Connaught, Phipps, Pasteur) $[21,22]$. Some countries had also used mixed BCG strains. The details of the type of BCG 
strain used for each of the countries with ongoing BCG vaccination was retrieved and collated from BCG World Atlas [13] and also the published reports [21, 22] and classified as early, late and mixed BCG strains.

\section{Grouping based on case fatality rates}

Based on their COVID-19 CFR, the 220 countries were divided into low, moderate and high risk groups. The cutoff values were determined as (a) low risk group with CFR $\leq 33^{\text {rd }}$ percentile (b) moderate risk group with CFR values between $34^{\text {th }}$ and $66^{\text {th }}$ percentile and (c) high risk group with CFR $>66^{\text {th }}$ percentile. The key epidemiological variables were estimated and the prognostic impact of these on the CFR for each of the 3 groups were evaluated.

\section{Statistical considerations: COVID-19 event rate and case fatality rate analysis}

COVID-19 events rates for each of the 220 countries were computed as events/nonevents. For each country, the events indicate the number of deaths, while nonevents were the difference between the number of confirmed cases and resulting deaths. Comprehensive Meta-analysis Software (version 3.0) was used to perform the event rate analysis [23].

The event rates for the three subgroups of BCG strains were compared using mixed effects model. The median value for each of the parameters namely - \%population aged $\geq 65$ years, incidences of IHD, HHD, cancer, malaria and diabetes; HDI and population density were used to create two distinct groups for each of these epidemiological covariate.

BCG vaccination was considered as a categorical variable based on the presence or absence of ongoing BCG vaccination program in each country. The effect of BCG vaccination have been studied to specifically estimate its impact on the high-risk groups of the other epidemiological variables. Comparative subgroup analysis for each of the above variables were carried out using 
mixed effects model and forest plots were generated along with point estimates, $95 \%$ confidence intervals, $Q$ value, $I^{2}$ and $p$ value.

For CFR, significance of comparison between two groups were reported using MannWhitney $\mathrm{U}$ test while for 3 groups, Kruskal-Wallis test [24] was used.

\section{Results}

\section{COVID-19: Case fatality rate}

Of the 220 countries and their dependent territories, 209 were represented in both the WHO and Worldometer websites while seven additional countries were extracted from the WHO [10] and four from Worldometer [11] public domains (Fig.1). As of July 30, 2020, a total of 17.3 million cases of COVID-19 have been reported from 220 countries worldwide (S1 Table). The total cases reported from these countries have ranged from 3 to 4.58 million (mean \pm SD: $78716.5 \pm 377563$ ). A total of 0.67 million deaths have been ascribed to COVID-19 and this varied between 0 to 0.15 million in these 220 countries. Consequently the COVID-19 CFR ranged from $0 \%$ to $28.3 \%$ (median: $2.1 \%$ ) (Fig.2a). The gross heterogeneity in the cases/million, deaths/million and COVID-19 CFR are evident from Table 1.

\section{Epidemiological parameters}

BCG immunization program for all inhabitants is currently underway in 144 of the 220 countries with \%coverage ranging between $37 \%$ and $99 \%(91.3 \% \pm 10.5$, median: $95 \%)$ (Table 1, Fig. 2 b). In 75 countries, either the BCG is advocated in selective high-risk subjects $(n=5)$ or has been suspended $(n=21)$. In the remaining 49 countries, either it was never used or details on the coverage was not available from both WHO and BCG Atlas sites $[12,13]$. All these 75 countries were thus categorized 
in the group of "BCG : not ongoing." One country not listed in the WHO or BCG World Atlas sites was excluded from computations related to BCG.

The distribution of the remaining epidemiological parameters evaluated were as follows \%population aged $\geq 65$ years ( $n=185,1.1 \%-27.6 \%$, median: $7.1 \%$ ), incidences of $\mathrm{IHD} / 10^{5}$ population ( $n=182,211-6769.9$, median: 1171 ), HHD/10 5 population ( $n=182,11.6-252$, median: 56.3 ), cancer ( $n=178,128-4514447$, median: 15726$)$, malaria $/ 10^{3}$ population ( $n=103,0.0-486$, median: 5.1 ) and \%diabetes ( $n=192,1.0-23.4$, median: 7.1\%); HDI ( $n=180,0.377-0.954$, median: 0.737 ) and population density/sq.km per land area ( $n=195,0.1-20,777.5$, median: 90.3) (Table 1).

\section{Groups based on case-fatality rates}

Based on the percentiles of COVID-19 CFR as defined above, 75, 67 and 78 countries were classified into low, moderate and high-risk. Each of the epidemiological variables were estimated for these groups and compared. The variables found to be significant in terms of the COVID-19 CFR were \% BCG coverage $(p=0.004)$, \%population aged $\geq 65$ years $(p=0.001)$, incidences of $I H D / 10^{5}$ population $(p=0.016)$ and cancer $(p<0.001)$ (Table 2, Figs. $2 b-e)$. The incidence of HHD, diabetes, malaria, HDI and population densities were not found to have any significant impact on the countries grouped as per the COVID-19 CFR.

\section{Epidemiological parameters vs COVID-19 event rate and case fatality rate}

Countries in which the BCG immunization program is ongoing has a significantly lesser event rate compared to those where this not being advocated $(0.034$ vs $0.020, p<0.001)$. For the remaining variables, these were divided into two groups based on the corresponding median values. The covariates found to be significantly influencing the COVID-19 event rate were - \%population aged $\geq 65$ years, $\leq 7.1 \%$ vs. $>7.1 \%(0.018$ vs. $0.028, p<0.001)$, incidences of $\mathrm{IHD} / 10^{5}$ population, $\leq 1171$ vs $>1171$ (0.018 vs. $0.027, p<0.001)$, cancer incidence, $\leq 15726$ vs. $>15726(0.018$ vs. $0.026, p=0.003)$ and $\mathrm{HDI}, \leq 0.737$ vs $>0.737,\left(0.019\right.$ vs. $0.026, p=0.003$ ) (Figs. $2 \mathrm{~b}-\mathrm{f}$ ). $\mathrm{HHD} / 10^{5}$ population $(\leq 56.26$ vs > 
56.26), malaria $/ 10^{3}$ population ( $\leq 5.12$ vs $>5.12$ ), \%diabetes prevalence $(\leq 7.15$ vs $>7.15$ ) and population density/sq. $\mathrm{km}(\leq 90.3$ vs $>90.3$ ) had no significant impact on the COVID-19 event rate (Fig. 3).

The COVID-19 CFR were also compared for the two groups of all the epidemiological parameters. These are summarized as - for BCG, ongoing vs not ongoing (median CFR: $2 \%$ vs $2.65 \%$, $\mathrm{p}=0.04$ ), \%population aged $\geq 65$ years, $\leq 7.1 \%$ vs. $>7.1 \%$ (median CFR: $1.7 \%$ vs $2.8 \%, p=0.004$ ), incidences of $\mathrm{IHD} / 10^{5}$ population, $\leq 1171$ vs $>1171$ (median CFR: $1.9 \%$ vs $2.5 \%, \mathrm{p}=0.01$ ), cancer incidence, $\leq 15726$ vs. $>15726$ (median CFR: $1.7 \%$ vs $2.8 \%, p=0.001$ ) and $\mathrm{HDI}, \leq 0.737$ vs $>0.737$, (median CFR: $1.7 \%$ vs $2.8 \%, p=0.002$ ). No significant differences were observed with incidence of HHD, malaria and diabetes and population densities of these countries. Thus the influence of epidemiological covariates on COVID-19 event rates and CFR were in good agreement.

\section{Impact of BCG on the higher risk subgroups of significant epidemiological parameters}

BCG vaccination was found to significantly reduce the COVID-19 event rate for each of the high-risk subgroups of key epidemiological covariates. Thus event rates for BCG vaccination (not ongoing vs. ongoing) for each of the high risk subgroups were - \%population of $65+$ years $>7.1 \%$ (0.036 vs 0.023 , $\mathrm{p}=0.008)$, IHD $>1171 / 10^{5}(0.035$ vs $0.022, \mathrm{p}=0.004), \mathrm{HDI}>0.737$ (0.037 vs $\left.0.020, \mathrm{p}=0.001\right)$, and cancer incidence $>15726$ (0.043 vs $0.022, \mathrm{p}<0.001)$ (Fig.4).

\section{Impact of type of BCG strains on COVID-19 case fatality rate}

Of the 144 countries with ongoing BCG vaccination program, the type of strains used was available in 127. Of these, 35 countries advocated early BCG strains while in 27 , late BCG strains was used for immunization. Mixed strains was adopted in 65 countries. The COVID-19 event rates computed were $0.018,0.031$ and 0.019 for early, late and mixed strains respectively ( $p=0.008$ ) (Fig. 5). 


\section{Discussion}

The ferocity of development of COVID-19 pandemic has led to an unprecedented thrust to accept the challenge and explore various options to help lessen its global impact on health, economy and society. While the search continues to find the most optimum therapeutic combination, the quest for a specific vaccine directed towards SARS-CoV-2 remains the ultimate focus of the current global research. Concurrently, a number of reports have looked into the various demographical factors that appear to influence the prevalence and mortality of COVID-19 [1-9]. However, even if these could attribute towards the prevalence and mortality of COVID-19, the ability to effectively modify these variables through prospective interventions are limited.

One of the variables, \%BCG coverage has widely varied across the 220 countries facing the pandemic $[12,13]$. BCG provides heterologous immunoprotection against a wide range of microbes including respiratory and yellow fever viruses [25-28]. The nonspecific protection offered by BCG vaccine could be due to similarities between the viral and the BCG antigens, antigen independent activation of the bystander B- and T-cells or long-term activation and reprogramming of the innate immune cells [25]. This is proposed as development of "trained immunity"[29]. This immunity is independent of T- and B-cell memory and provides a nonspecific cross-protection contributed by the innate immune cells - macrophages and natural killer cells. An excellent summary of the possible mechanisms of BCG induced trained and its likely impact on COVID-19 has been recently outlined by O'Neill and Netea [7].

In view of the gross heterogeneity in the reported COVID-19 case fatality, the present study had evaluated the impact of various epidemiological parameters and their interactions on the outcomes covering a population of over 7.76 billion in 220 countries. Population $\geq 65$ years and associated comorbidities like IHD and cancer have shown to negatively influence the outcomes (Table 2 and Fig.3). The impact of HDI was not evident on the three group classifications based on 
COVID-19 CFR (Table 2). However, countries with higher HDI showed a significantly higher event rate (HDI: $\leq 0.737$ vs $>0.737$, event rate 0.019 vs. $0.026, p=0.003$ ) (Fig.3). This could be perhaps attributed to the fact that in most HDI countries had no ongoing BCG immunization for its population (Spearman correlation: $-0.162, \mathrm{p}=0.03$ ). Higher prevalence of diabetes, malaria and HHD along with a higher population density were not significantly associated with higher COVID-19 CFR in their group classification (Table 2) nor on the event rate (Fig.3).

$B C G$ vaccination has shown to mitigate the influence of $B C G$ on COVID-19 $[8,21,30,31]$. However, these studies have usually been reported looking at BCG only. Since we expect that other epidemiological parameters could also have an influence on the COVID-CFR, we examined the most relevant parameters that could be accessed in the public domains and thereby identify the high-risk population who could be most vulnerable and need protection. A reduction in the event rate from 0.034 with no active $B C G$ vaccination to 0.020 with ongoing $B C G$ immunization program represents a 41.1\% reduction in the event rate (Fig. 3a). Further BCG vaccination appears to significantly reduce the COVID-19 event rate in all high-risk subgroups of population $\geq 65$ years $(\downarrow 36.1 \%)$, higher incidences of IHD ( $\downarrow 37.1 \%)$, cancer ( $\downarrow 48.8 \%)$ and countries with higher HDI ( $\downarrow 45.9 \%)$ (Fig. 4).

The impact of immunogenicity induced by BCG could be dependent on the type of strains. The late strains are deficient in their ability to produce cell wall methoxymycolic acid which constitute an key group of ligands proficient in inducing trained immunity [21]. Our results lend support to this hypothesis as the event rate was significantly lower in countries using early strain BCG (0.18) (Fig.5). The event rate with late BCG strains of 0.031 was nearly the same as those countries without BCG vaccination at 0.034 (Figs. 3a and 5). In contrast, those with early and mixed strains, the event rates were nearly similar at 0.018 and 0.019 respectively.

As on July 30,2020 , of the 10 countries with the worst COVID-19 CFR ranging from $11.1 \%$ to $28.3 \%$, seven had no ongoing BCG vaccination program. Of the remaining three countries, two used late strains of BCG while one had mixed BCG strain. Even though the event rate for mixed BCG strain 
was nearly similar to those with early strain $(0.019$ vs 0.018 , Fig.5), the \%BCG coverage in this country (Yemen) was grossly inadequate at just 64\%. Thus, even though other key prognostic epidemiological covariates like population aged 65 years and above, incidence of IHD and cancer were favorable, but inadequate BCG vaccination coverage could have been one of the key contributing factors towards the highest recorded COVID CFR at $28.3 \%$ in Yemen.

The duration of lasting of the BCG induced trained immunity is of significance as BCG vaccination are usually given within 1-year of birth. Netea et al $[28,29]$ had demonstrated that the trained immunity status was maintained at least for one year which was the maximum observed time point in their report. A recent report [21] from 13 European countries who had suspended their $B C G$ vaccination program more than two decades ago, suggests that the BCG induced heterologous non-specific protective effect could even last for 20 years or more.

BCG vaccination may not be expected to reduce the number of positive cases, most of whom could recover through the "trained immunity" imparted by BCG. However as evident from this analysis and supported by other studies, BCG could reduce the fatal outcomes $[8,21,30,31]$. One could well argue that the results of this analysis would also depend on the number of tests performed. However, the testing would certainly influence the cases/million and deaths/million population estimates. Thus, to minimize the impact of testing, the impact of BCG at the fatality in those tested positive for COVID-19 was evaluated in this study. Even though a widespread testing would be desirable, one has to accept that the testing protocols adopted by countries are varied and depends on their individual policies, availability and logistics of carrying out these tests. These tests have not been used in most countries as a screening procedure for all subjects. However, tests would have been conducted in most of the suspected, symptomatic, contacts of positive patients, high-risk individuals and those subjected to compulsory screening (travelers etc.). Even with all the inherent limitations as discussed above, the present data should be construed as a reasonably 
adequate sample of more than 332.84 million test reports obtained globally reported as on July 30 , 2020.

Despite these constraints, the evidence of a likely protective effect of BCG vaccination on COVID-19 is apparent. It would be imperative to examine the effects of BCG vaccinations through well designed randomized clinical trials. Presently, four phase III randomized clinical trials have been initiated, one each in Netherlands (NCT04328441), Australia (NCT04327206), USA (NCT04348370) and South Africa (NCT04379336) [32]. These are being conducted in healthcare workers randomized between BCG and placebo injection of normal saline. The outcomes from these studies would confirm the observational findings of a potential benefit of BCG vaccination against COVID-19.

The data from 220 countries and dependent territories represents 7.76 billion inhabitants globally [33]. Even though this is an observational study, the alleviating impact of BCG vaccination on COVID-19 cannot just be overlooked while we are still investigating to arrive at the optimum pharmacotherapy and racing against time towards developing a specific vaccine. However, the results of this analysis should not be construed as a gateway for advocating BCG vaccination for all. Nor should it deliver a false sense of security and complacency to those who have been previously vaccinated. It does not in any way dilute the usual precautions to be adopted for preventing COVID19. Nonetheless, it does support the hypothesis of "trained immunity" with BCG vaccination. Pending the results of the ongoing phase III clinical trials, the study could be considered as suggestive of a cost-effective prophylaxis by BCG vaccination especially for high-risk population. In countries which already have an ongoing BCG vaccination during neonatal period, the effectivity of a booster dose of BCG selective for high-risk population needs careful evaluation and is beyond the scope of this manuscript.

The conclusions derived from this study could be further examined through study of individual cases and needs joint efforts from various national and international agencies. This study, however provides a pragmatic rationale for BCG vaccination with early strains in high-risk individuals 
to reduce the COVID-19 case fatality to bridge the gap till an effective vaccine specifically against SARS-CoV-2 is freely available globally.

\section{Acknowledgement}

We acknowledge the inputs from Prof. M. Borenstein on the analysis and Dr. Indranil Pan for his support and guidance regarding programming in Python for data extraction and analysis. Discussions with Prof. C.M. Pandey is also gratefully acknowledged.

\section{Supporting information}

S1 Table: COVID-19 status shown as cases/million, deaths/million, case fatality rate as on July 30, 2020 for \% BCG vaccination in 1-yr old, \% population aged 65+ years, human development index (HDI), ischemic heart disease (IHD) $/ 10^{5}$ population, hypertensive heart disease (HHD) $/ 10^{5}$ population, cancer incidence, incidence of malaria/1000 at risk, diabetes prevalence ( $20-79$ years), population density (PD)/sq.km of land area and BCG strain

\section{Authors contributions}

Conceptualization: Niloy R. Datta

Data curation: Sneha Datta and Niloy R. Datta

Formal analysis: Niloy R. Datta

Supervision: Niloy R. Datta 
medRxiv preprint doi: https://doi.org/10.1101/2020.08.12.20173617; this version posted August 14, 2020. The copyright holder for this preprint (which was not certified by peer review) is the author/funder, who has granted medRxiv a license to display the preprint in perpetuity.

All rights reserved. No reuse allowed without permission.

Writing original draft: Niloy R. Datta and Sneha Datta

Writing- reviewing and editing: Niloy R. Datta and Sneha Datta 


\section{Figure legends}

Fig.1 Flow chart indicating the sources of COVID-19 case fatality and the availability of the data for the relevant epidemiological parameters retrieved from the public domains of various websites. The details of the websites from where the data have been extracted are mentioned in the text.

Fig.2 Global distribution map of (a) \%case fatality rate due to COVID-19 as reported on July 7, 2020 (b) \% BCG coverage (c) \% population aged 65+ years (d) Ischemic heart disease $/ 10^{5}$ population (e) Human development index (f) Cancer incidence (2020).

Fig.3 Forest plots for subgroup analysis for covariates for COVID-19 case fatality rate as on July 7, 2020 (a) BCG vaccination in various countries (not ongoing vs ongoing) (b) \%Population aged $65+$ years (c) Ischemic heart disease $/ 10^{5}$ population (d) Human development index (e) Cancer incidence (f) Incidence of malaria/1000 at risk (g) Hypertensive heart disease $/ 10^{5}$ population (h) Diabetes prevalence (20-79 years) and (i) Population density/sq.km of land area

Fig.4 Impact of the none/ suspended vs. ongoing BCG vaccination programme on the COVID-19 case mortality rates for the high risk population (a) \% Population aged $65+$ years $(>7.1 \%)$ (b) Ischemic heart disease $/ 10^{5}$ population $\left(>1171 / 10^{5}\right.$ ) (c) Human development index (> $0.737)$ and (d) Cancer incidence (> 56.25)

Fig.5 Impact of BCG strains on the COVID-19 case fatality rates in countries with ongoing BCG vaccination. This represent 127 of the 144 countries for which the BCG vaccination strains were available. 
medRxiv preprint doi: https://doi.org/10.1101/2020.08.12.20173617; this version posted August 14, 2020. The copyright holder for this preprint (which was not certified by peer review) is the author/funder, who has granted medRxiv a license to display the preprint in perpetuity.

All rights reserved. No reuse allowed without permission. 


\section{References}

1. Zhang X. Epidemiology of Covid-19. The New England journal of medicine. 2020;382. Epub 2020/03/29. doi: 10.1056/NEJMc2005157. PubMed PMID: 32220200.

2. Yang J, Zheng Y, Gou X, Pu K, Chen Z, Guo Q, et al. Prevalence of comorbidities and its effects in patients infected with SARS-CoV-2: a systematic review and meta-analysis. International journal of infectious diseases : IJID : official publication of the International Society for Infectious Diseases. 2020;94:91-5. Epub 2020/03/17. doi: 10.1016/j.ijid.2020.03.017. PubMed PMID: 32173574; PubMed Central PMCID: PMCPMC7194638.

3. Wu ZH, Tang $\mathrm{Y}$, Cheng $\mathrm{Q}$. Diabetes increases the mortality of patients with COVID-19: a meta-analysis. Acta diabetologica. 2020:1-6. Epub 2020/06/26. doi: 10.1007/s00592-02001546-0. PubMed PMID: 32583078; PubMed Central PMCID: PMCPMC7311595.

4. Sinclair AJ, Abdelhafiz AH. Age, frailty and diabetes - triple jeopardy for vulnerability to COVID-19 infection. EClinicalMedicine. 2020:100343. Epub 2020/04/25. doi: 10.1016/j.eclinm.2020.100343. PubMed PMID: 32328575; PubMed Central PMCID: PMCPMC7177130.

5. Pranata R, Lim MA, Huang I, Raharjo SB, Lukito AA. Hypertension is associated with increased mortality and severity of disease in COVID-19 pneumonia: A systematic review, meta-analysis and meta-regression. Journal of the renin-angiotensin-aldosterone system : JRAAS. 2020;21(2):1470320320926899. Epub 2020/05/16. doi: 10.1177/1470320320926899. PubMed PMID: 32408793; PubMed Central PMCID: PMCPMC7231906.

6. Pranata R, Huang I, Lim MA, Wahjoepramono PEJ, July J. Impact of Cerebrovascular and Cardiovascular Diseases on Mortality and Severity of COVID-19 - Systematic Review, Metaanalysis, and Meta-regression. Journal of stroke and cerebrovascular diseases : the official journal of National Stroke Association. 2020;29(8):104949. Epub 2020/05/16. doi: 10.1016/j.jstrokecerebrovasdis.2020.104949. PubMed PMID: 32410807; PubMed Central PMCID: PMCPMC7221373.

7. O'Neill LAJ, Netea MG. BCG-induced trained immunity: can it offer protection against COVID-19? Nature reviews Immunology. 2020;20(6):335-7. Epub 2020/05/13. doi: 10.1038/s41577-020-0337-y. PubMed PMID: 32393823; PubMed Central PMCID: PMCPMC7212510.

8. Miyasaka M. Is BCG vaccination causally related to reduced COVID-19 mortality? EMBO molecular medicine. 2020;12(6):e12661. Epub 2020/05/08. doi: 10.15252/emmm.202012661. PubMed PMID: 32379923; PubMed Central PMCID: PMCPMC7267326.

9. Ahmed AE. Incidence of coronavirus disease (COVID-19) and countries affected by malarial infections. Travel medicine and infectious disease. 2020:101693. Epub 2020/04/26. doi: 10.1016/j.tmaid.2020.101693. PubMed PMID: 32334084; PubMed Central PMCID: PMCPMC7194665 disclosure.

10. World Health Organization (WHO). WHO Coronavirus Disease (COVID-19) dashboard Geneva, Switzerland: WHO; [July 7, 2020]. Available from: https://covid19.who.int/. 
11. Worldometer. Covid-19 coronavirus pandemic: Worldometer; [July 7, 2020]. Available from: https://www.worldometers.info/coronavirus/.

12. World Health Organization (WHO). BCG immunization coverage among 1-year-olds (\%) Geneva, Switzerland: WHO; [June 28, 2020]. Available from: https://www.who.int/data/gho/data/indicators/indicator-details/GHO/bcg-immunizationcoverage-among-1-year-olds-(-).

13. The BCG World Atlas, 2nd edition [May 14, 2020)]. Available from: http://www.bcgatlas.org/index.php.

14. The World Bank. Population ages 65 and above (\% of total population): The World Bank; [July 1, 2020]. Available from: https://data.worldbank.org/indicator/SP.POP.65UP.TO.ZS.

15. Roth GA, Johnson C, Abajobir A, Abd-Allah F, Abera SF, Abyu G, et al. Global, Regional, and National Burden of Cardiovascular Diseases for 10 Causes, 1990 to 2015. J Am Coll Cardiol. 2017;70(1):1-25. doi: 10.1016/j.jacc.2017.04.052. PubMed PMID: 28527533; PubMed Central PMCID: PMCPMC5491406.

16. International Agency for Research on Cancer. Cancer tomorrow: International Agency for Research on Cancer, WHO; [July 1, 2020]. Available from: https://gco.iarc.fr/tomorrow/graphicisotype?type $=0$ \&type $\operatorname{sex}=0 \&$ mode $=$ population $\&$ sex $=0$ \&populations $=887 \&$ cancers $=39 \&$ ag e group $=$ value \&apc male $=0 \& a p c$ female $=0 \&$ single unit $=1000000$ \&print $=0 \#$ collapseothers.

17. World Health Organization. Malaria incidence (per 1000 population at risk): World Health Organization; [July 5, 2020]. Available from: https://www. who.int/data/gho/data/indicators/indicator-details/GHO/malaria-incidence(per-1-000-population-at-risk).

18. Roser M, Ritchie H. Burden of Disease Published online at OurWorldInData.org [July 1, 2020]. Available from: https://ourworldindata.org/burden-of-disease\#all-charts-preview.

19. United Nations Development Programme. Human Development Reports: 2019 Human Development Index Ranking United Nations Development Programme [June 23, 2020]. Available from: http://hdr.undp.org/en/content/2019-human-development-in dex-ranking.

20. The World Bank. Population density (people per sq. km of land area): The World Bank; [June 23, 2020]. Available from: https://data.worldbank.org/indicator/EN.POP.DNST.

21. Gursel $M$, Gursel I. Is global BCG vaccination-induced trained immunity relevant to the progression of SARS-CoV-2 pandemic? Allergy. 2020. Epub 2020/04/28. doi: 10.1111/all.14345. PubMed PMID: 32339299.

22. Ritz N, Curtis N. Mapping the global use of different BCG vaccine strains. Tuberculosis (Edinb). 2009;89(4):248-51. doi: 10.1016/j.tube.2009.03.002. PubMed PMID: 19540166.

23. Comprehensive Meta-analysis Software, version 3.0 accessed Aug 8, 2016 [Aug 8, 2016.]. Available from: https://www.meta-analysis.com/.

24. Kruskal WH, Wallis WA. Use of Ranks in One-Criterion Variance Analysis. Journal of the American Statistical Association. 1952;47(260):583-621. doi: 10.1080/01621459.1952.10483441.

25. Redelman-Sidi G. Could BCG be used to protect against COVID-19? Nature reviews Urology. 2020. Epub 2020/04/29. doi: 10.1038/s41585-020-0325-9. PubMed PMID: 32341531.

26. Arts RJW, Moorlag S, Novakovic B, Li Y, Wang SY, Oosting M, et al. BCG vaccination protects against experimental viral infection in humans through the induction of cytokines 
associated with trained immunity. Cell Host Microbe. 2018;23(1):89-100 e5. doi: 10.1016/j.chom.2017.12.010. PubMed PMID: 29324233.

27. Kleinnijenhuis J, Quintin J, Preijers F, Benn CS, Joosten LA, Jacobs C, et al. Long-lasting effects of BCG vaccination on both heterologous Th1/Th17 responses and innate trained immunity. J Innate Immun. 2014;6(2):152-8. doi: 10.1159/000355628. PubMed PMID: 24192057; PubMed Central PMCID: PMCPMC3944069.

28. Netea MG, van Crevel R. BCG-induced protection: effects on innate immune memory. Seminars in immunology. 2014;26(6):512-7. Epub 2014/12/03. doi: 10.1016/j.smim.2014.09.006. PubMed PMID: 25444548.

29. Netea MG, Quintin J, van der Meer JW. Trained immunity: a memory for innate host defense. Cell Host Microbe. 2011;9(5):355-61. doi: 10.1016/j.chom.2011.04.006. PubMed PMID: 21575907.

30. Hegarty PK, Sfakianos JP, Giannarini G, DiNardo AR, Kamat AM. COVID-19 and Bacillus Calmette-Guerin: What is the Link? European urology oncology. 2020. Epub 2020/04/25. doi: 10.1016/j.euo.2020.04.001. PubMed PMID: 32327396; PubMed Central PMCID: PMCPMC7152883.

31. Ozdemir C, Kucuksezer UC, Tamay ZU. Is BCG vaccination effecting the spread and severity of COVID-19? Allergy. 2020. Epub 2020/04/25. doi: 10.1111/all.14344. PubMed PMID: 32330314.

32. ClinicalTrials.gov: US National Library of Medicine; 2020 [May 19, 2020)]. Available from: https://clinicaltrials.gov/ct2/results?cond=COVID$19+$ AND+BCG\&term $=\&$ cntry $=$ \&state $=\&$ city $=$ \&dist $=$.

33. Worldometer. Countries in the world by population 2020 [May 22, 2020]. Available from: https://www.worldometers.info/world-population/population-by-country/. 
medRxiv preprint doi: https://doi.org/10.1101/2020.08.12.20173617; this version posted August 14, 2020. The copyright holder for this preprint (which was not certified by peer review) is the author/funder, who has granted medRxiv a license to display the preprint in perpetuity.

All rights reserved. No reuse allowed without permission.

Table 1: Profile of the epidemiological demographic parameters as on July 30, 2020.

\begin{tabular}{|c|c|c|c|}
\hline Epidemiological parameters & Number & Range & Mean \pm SD \\
\hline COVID -19 cases / million ${ }^{a}$ & 220 & $3.0-39340.0$ & $2905.1 \pm 4849.7$ \\
\hline COVID-19 deaths / million ${ }^{a}$ & 220 & $0.0-1238.0$ & $83.51 \pm 161.8$ \\
\hline COVID -19 case fatality rate ${ }^{a}(\%)$ & 220 & $0.0-28.3$ & $3.05 \pm 3.5$ \\
\hline$\%$ BCG vaccination in 1-yr old ${ }^{b}$ & 144 & $37.0-99.0$ & $91.3 \pm 10.5$ \\
\hline$\%$ Population aged $65+$ years & 185 & $1.1-27.6$ & $9.11 \pm 6.3$ \\
\hline Ischemic heart disease $/ 10^{5}$ population & 182 & $211-6769.9$ & $1520.5 \pm 1184.2$ \\
\hline Hypertensive heart disease $/ 10^{5}$ population & 182 & $11.6-252.0$ & $70.8 \pm 45.3$ \\
\hline Cancer incidence & 178 & $128-4514447$ & $105001.5 \pm 399501.9$ \\
\hline Diabetes prevalence ( $20-79$ years) & 192 & $1.0-23.4$ & $8.1 \pm 4.2$ \\
\hline Incidence of malaria/1000 at risk & 103 & $0.0-486.0$ & $86.1 \pm 129.4$ \\
\hline Human development index & 180 & $0.377-0.954$ & $0.715 \pm 0.153$ \\
\hline Population density/sq.km of land area & 195 & $0.1-20777.5$ & $373.3 \pm 1683.5$ \\
\hline \multicolumn{4}{|l|}{ a as on July 30,2020} \\
\hline
\end{tabular}


medRxiv preprint doi: https://doi.org/10.1101/2020.08.12.20173617; this version posted August 14, 2020. The copyright holder for this preprint (which was not certified by peer review) is the author/funder, who has granted medRxiv a license to display the preprint in perpetuity. All rights reserved. No reuse allowed without permission.

Table 2: Impact of demographic variables on the COVID-19 case fatality rates as on July 30, 2020 of 220 countries grouped as low $(\leq 1.3 \%)$, moderate $(1.4 \%-3.1 \%)$ and high $(>3.2 \%)$.

\begin{tabular}{|c|c|c|c|c|}
\hline \multicolumn{2}{|l|}{ Parameters } & \multicolumn{3}{|c|}{$\%$ COVID-19 case fatality rate } \\
\hline & & $\begin{array}{l}\text { Low risk } \\
\begin{array}{c}(\leq 1.3 \%) \\
(n=75)\end{array}\end{array}$ & $\begin{array}{l}\text { Moderate risk } \\
\begin{array}{c}(1.4 \%-3.1 \%) \\
(n=67)\end{array}\end{array}$ & $\begin{array}{l}\text { High risk } \\
\begin{array}{c}(\geq 3.1 \%) \\
(n=78)\end{array}\end{array}$ \\
\hline \multirow[t]{4}{*}{$\% \mathrm{BCG}_{\text {coverage }}{ }^{\mathrm{a}}$} & Number & 74 & 67 & 78 \\
\hline & Mean \pm SD & $61.0 \pm 45.5$ & $73.5 \pm 36.5$ & $47.8 \pm 45.6$ \\
\hline & Median & 99.0 & 92.0 & 66.5 \\
\hline & & \multicolumn{3}{|c|}{$p=0.004^{j}$} \\
\hline \multirow[t]{4}{*}{ Age $(65+)$ years $^{b}$} & Number & 58 & 64 & 63 \\
\hline & Mean \pm SD & $6.8 \pm 4.6$ & $8.8 \pm 6.1$ & $11.6 \pm 7.1$ \\
\hline & Median & 4.9 & 6.8 & 10.7 \\
\hline & & \multicolumn{3}{|c|}{$p=0.001^{j}$} \\
\hline \multirow[t]{4}{*}{$\mathrm{IHD}^{\mathrm{c}}$} & Number & 57 & 62 & 63 \\
\hline & Mean \pm SD & $1191.6 \pm 832.8$ & $1591.1 \pm 1413.2$ & $1748.7 \pm 1159.7$ \\
\hline & Median & 991.3 & 1151.2 & 1497.0 \\
\hline & & \multicolumn{3}{|c|}{$p=0.016^{j}$} \\
\hline \multirow[t]{4}{*}{ Cancer $(2020)^{d}$} & Number & 55 & 62 & 61 \\
\hline & Mean \pm SD & $21.595 .9 \pm 41078.3$ & $83292.1 \pm 203235.7$ & $202268.6 \pm 640960.9$ \\
\hline & Median & 7707 & 12950 & 34296 \\
\hline & & \multicolumn{3}{|c|}{$\mathrm{p}<0.001^{\mathrm{j}}$} \\
\hline \multirow[t]{4}{*}{$\mathrm{HDI}^{\mathrm{e}}$} & Number & 58 & 60 & 62 \\
\hline & Mean \pm SD & $0.70 \pm 0.1$ & $0.69 \pm 0.1$ & $0.75 \pm 0.2$ \\
\hline & Median & 0.72 & 0.72 & 0.76 \\
\hline & & \multicolumn{3}{|c|}{$p: n s^{j}$} \\
\hline \multirow[t]{4}{*}{$H H D^{f}$} & Number & 57 & 62 & 63 \\
\hline & Mean \pm SD & $66.8 \pm 46.7$ & $74.6 \pm 43.9$ & $70.5 \pm 45.5$ \\
\hline & Median & 52.4 & 62.3 & 55.1 \\
\hline & & \multicolumn{3}{|c|}{$p: n s^{j}$} \\
\hline \multirow[t]{2}{*}{ Diabetes $^{g}$} & Number & 63 & 62 & 67 \\
\hline & Mean \pm SD & $8.8 \pm 4.8$ & $7.6 \pm 4.1$ & $7.7 \pm 3.7$ \\
\hline
\end{tabular}




\begin{tabular}{|c|c|c|c|c|}
\hline \multirow{2}{*}{\multicolumn{2}{|c|}{ Parameters }} & \multicolumn{3}{|c|}{$\%$ COVID-19 case fatality rate } \\
\hline & & \multirow{2}{*}{$\begin{array}{l}\text { Low risk } \\
\begin{array}{l}(\leq 1.3 \%) \\
(n=75)\end{array} \\
\end{array}$} & \multirow{2}{*}{$\begin{array}{l}\text { Moderate risk } \\
\begin{array}{l}(1.4 \%-3.1 \%) \\
(n=67)\end{array} \\
\end{array}$} & \multirow{2}{*}{$\begin{array}{l}\text { High risk } \\
\begin{array}{l}(\geq 3.1 \%) \\
(n=78) \\
\end{array}\end{array}$} \\
\hline & Median & & & \\
\hline & & \multicolumn{3}{|c|}{$p: n s^{j}$} \\
\hline \multirow[t]{4}{*}{ Malaria $^{\mathrm{h}}$} & Number & 33 & 40 & 30 \\
\hline & Mean \pm SD & $94.7 \pm 140.2$ & $75.5 \pm 114.8$ & $90.9 \pm 138.6$ \\
\hline & Median & 4.2 & 4.4 & 6.1 \\
\hline & & \multicolumn{3}{|c|}{$p: n s^{j}$} \\
\hline \multirow[t]{4}{*}{$\mathrm{PD} / \mathrm{sq} \cdot \mathrm{km}^{\mathrm{i}}$} & Number & 64 & 64 & 67 \\
\hline & Mean \pm SD & $835.9 \pm 2887.1$ & $152.9 \pm 160.9$ & $141.8 \pm 202.6$ \\
\hline & Median & 97.9 & 84.0 & 83.3 \\
\hline & & \multicolumn{3}{|c|}{$p: n s^{j}$} \\
\hline \multicolumn{5}{|c|}{${ }^{\mathrm{a}}$ BCG vaccine in 1-yr old (2018) (Countries with no ongoing BCG coverage } \\
\hline \multicolumn{5}{|c|}{ b\%Population aged $65+$ years $(2018)$} \\
\hline \multicolumn{5}{|c|}{${ }^{c}$ Ischemic heart disease (IHD) : Prevalence for both sexes / $10^{5}$ individuals (2015) } \\
\hline \multicolumn{5}{|c|}{ d Cancer incidence (2020) } \\
\hline \multicolumn{5}{|c|}{${ }^{\mathrm{e}} \mathrm{HDI}$ : Human development index (2019) } \\
\hline \multicolumn{5}{|c|}{${ }^{f}$ Hypertensive heart disease (HHD) : Prevalence for both sexes / $10^{5}$ individuals (2015) } \\
\hline \multicolumn{5}{|c|}{${ }^{\mathrm{g}}$ Prevalence of diabetes in \% population in age group $20-79$ years (2017) } \\
\hline \multicolumn{5}{|c|}{${ }^{h}$ Incidence of malaria (2018) } \\
\hline \multicolumn{5}{|c|}{ ' Population density (PD): People per sq. km of land area (2018) } \\
\hline j Kruskal-Wa & & & & \\
\hline
\end{tabular}


Fig. 1 Flow chart indicating the sources of COVID-19 case fatality and the availability of the data for the relevant epidemiological parameters retrieved from the public domains of various websites. The details of the websites from where the data have been extracted are mentioned in the text.

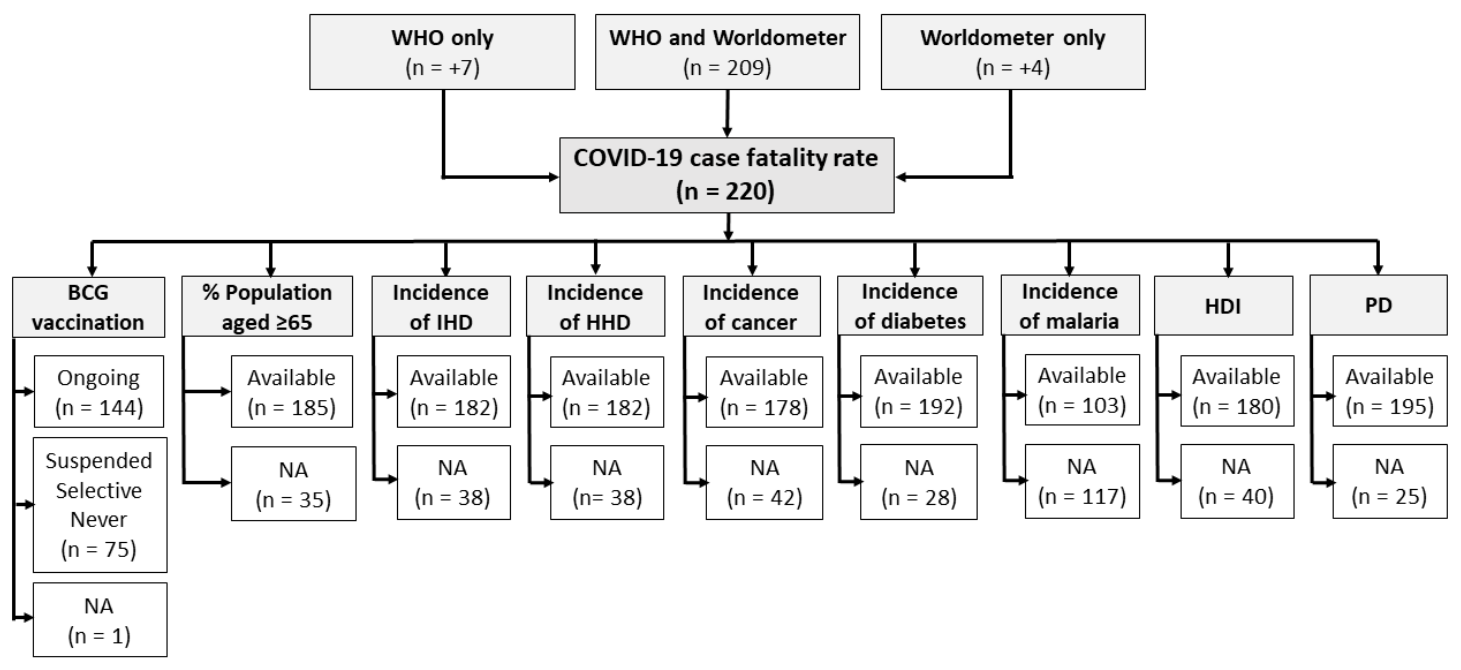

IHD: Ischemic heart disease; HHD: Hypertensive heart disease; HDI: Human development index; PD: Population density; NA: Not available 
medRxiv preprint doi: https://doi.org/10.1101/2020.08.12.20173617; this version posted August 14, 2020. The copyright holder for this preprint (which was not certified by peer review) is the author/funder, who has granted medRxiv a license to display the preprint in perpetuity.

All rights reserved. No reuse allowed without permission.

Fig. 2 Global distribution map of (a) \%case fatality rate due to COVID-19 as reported on July 7, 2020

(b) \% BCG coverage (c) \% population aged $65+$ years (d) Ischemic heart disease $/ 10^{5}$ population (e)

Human development index (f) Cancer incidence (2020).
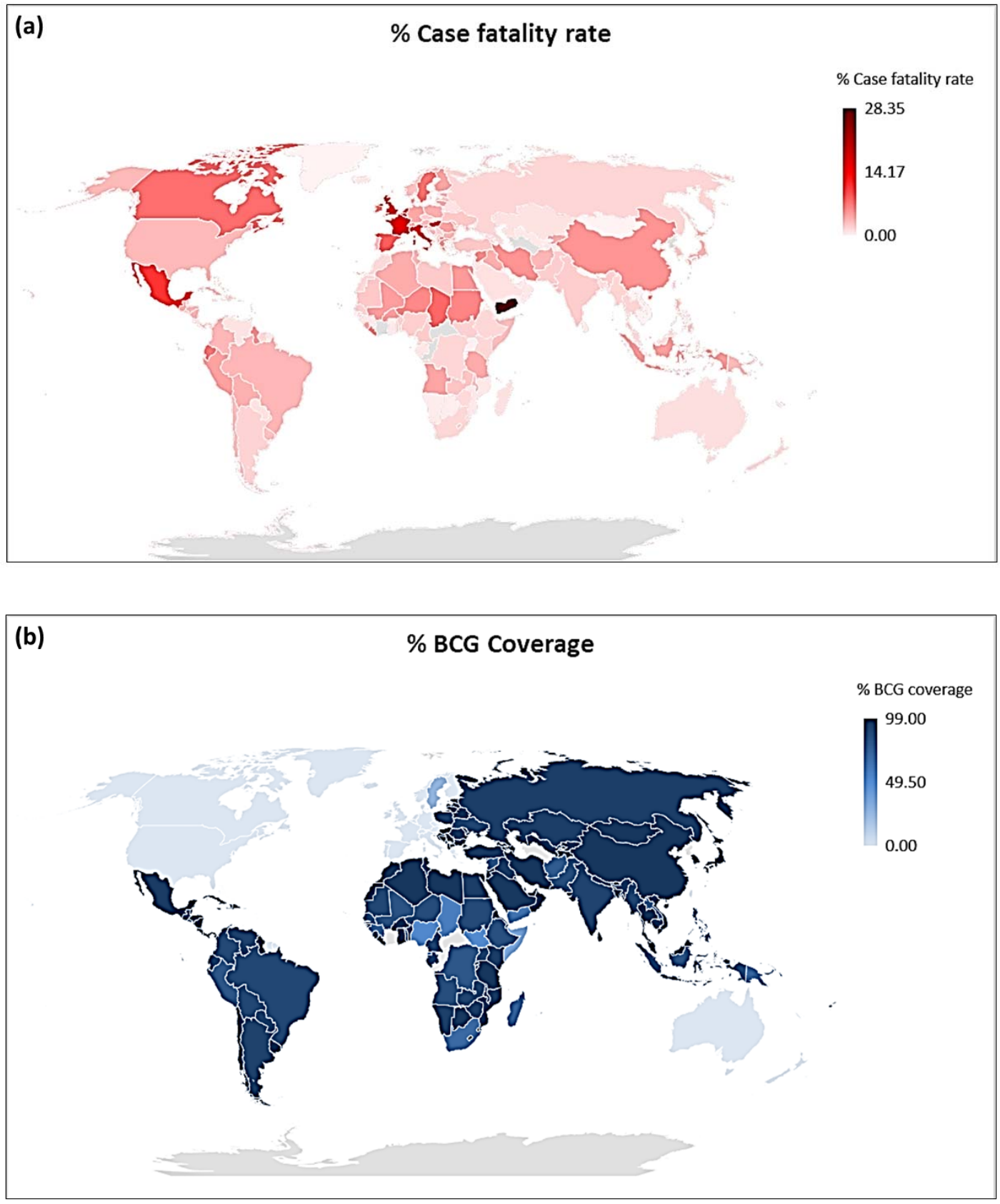

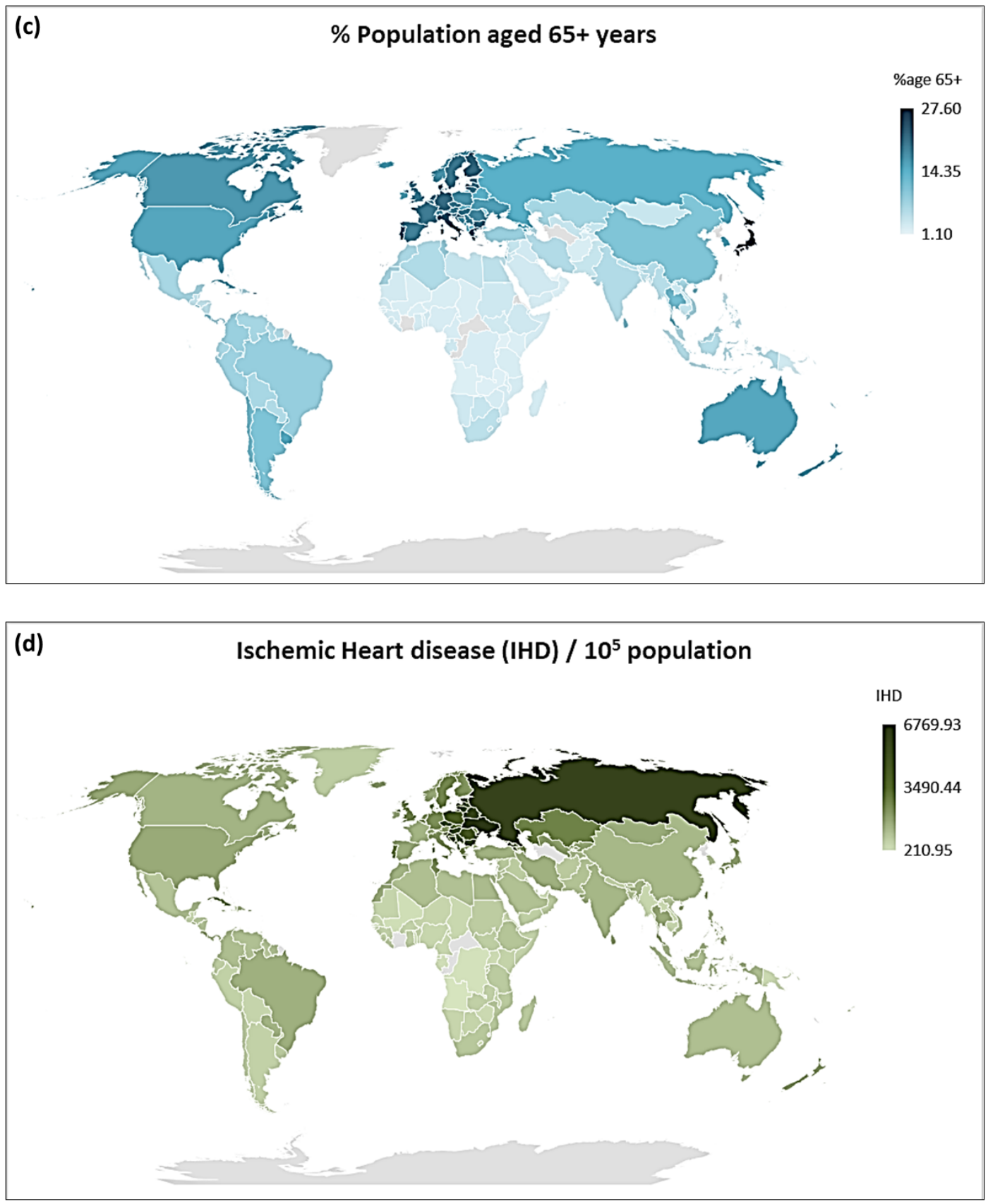

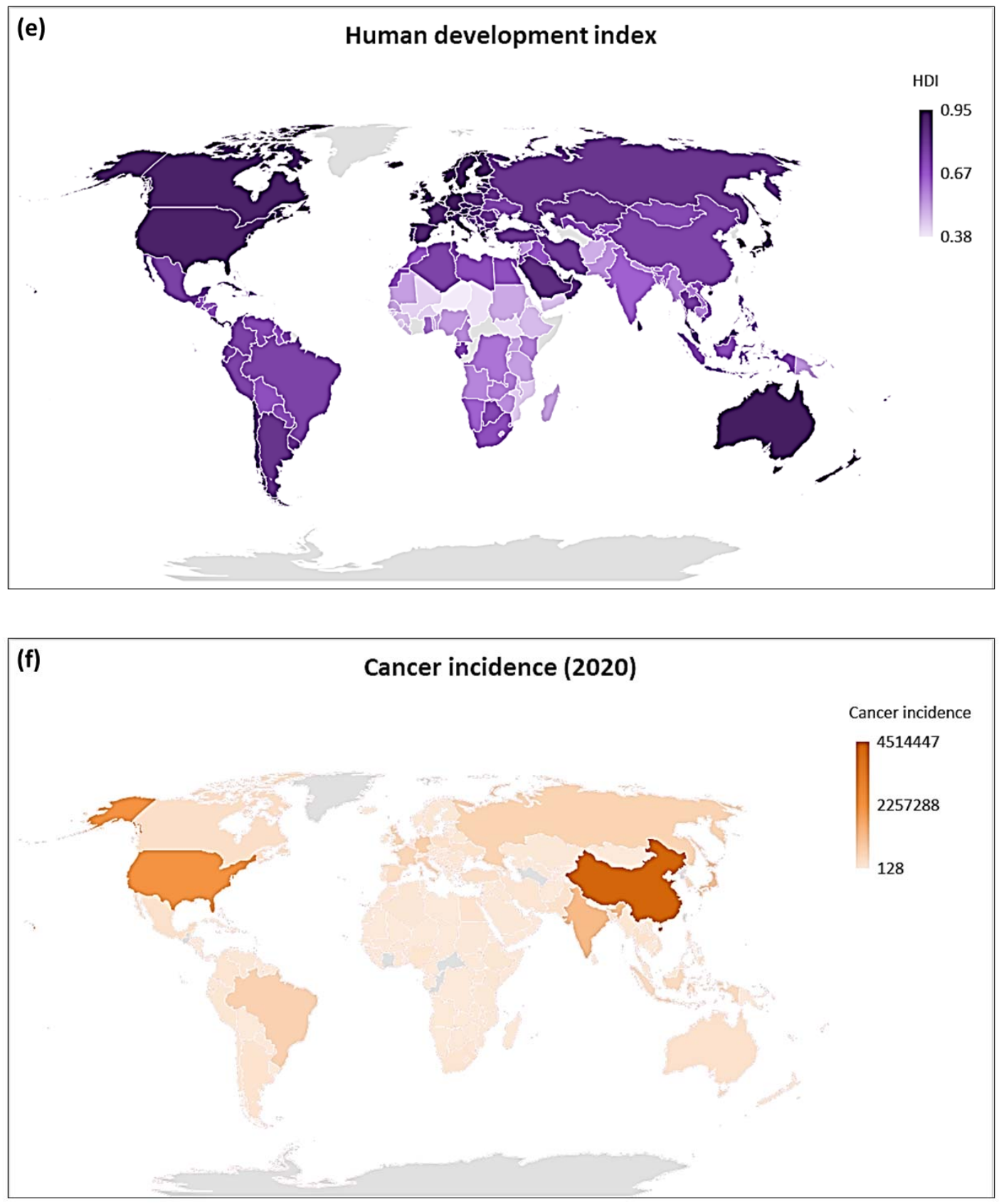
Fig. 3 Forest plots for subgroup analysis for covariates for COVID-19 case fatality rate as on July 7 , 2020 (a) BCG vaccination in various countries (not ongoing vs ongoing) (b) \%Population aged 65+ years (c) Ischemic heart disease $/ 10^{5}$ population (d) Human development index (e) Cancer incidence (f) Incidence of malaria/1000 at risk (g) Hypertensive heart disease $/ 10^{5}$ population (h) Diabetes prevalence ( $20-79$ years) and (i) Population density/sq.km of land area

\section{(a) Group: BCG vacclnatlon}

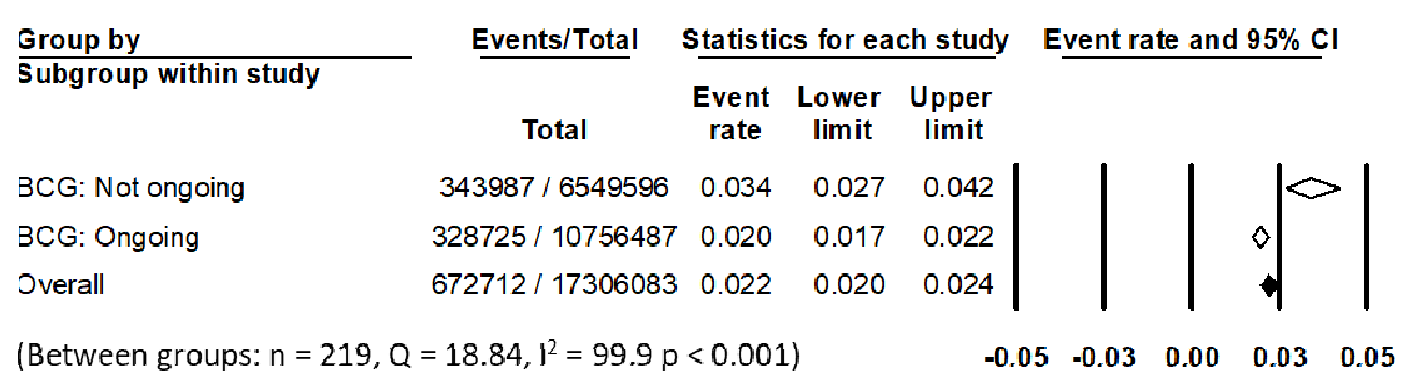

\section{(b) Group: \% populatlon aged 65+ years}

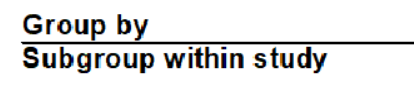

Age $65+</=7.1 \%$

Age $65+>7.1 \%$

Overall

(Between groups: $\mathrm{n}=185, \mathrm{Q}=19.31, \mathrm{I}^{2}=99.9 \mathrm{p}<0.001$ )

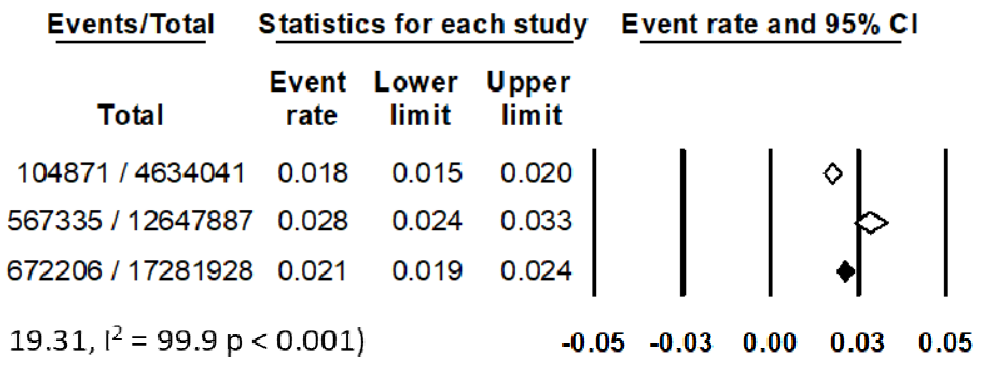

\section{(c) Group: Ischemic heart disease (IHD)}

Group by

Subgroup within study

IHD $</=1171 / 100,000$

IHD $>1171 / 100,000$

Overall

(Between

(Between groups: $\mathrm{n}=182, \mathrm{Q}=9.46, \mathrm{I}^{2}=99.9 \mathrm{p}<0.001$ )
Events/Total Statistics for each study Event rate and $95 \% \mathrm{Cl}$

Total Event $\begin{gathered}\text { Lower } \\ \text { rate }\end{gathered}$ Upper

$\begin{array}{cccc}126877 / 3831514 & 0.018 & 0.015 & 0.022 \\ 544876 / 13446245 & 0.027 & 0.023 & 0.031 \\ 671753 / 17277759 & 0.022 & 0.020 & 0.026\end{array}$

$\begin{array}{lllll}-0.05 & -0.03 & 0.00 & 0.03 & 0.05\end{array}$ 


\section{(d) Group: Human development index (HDI)}

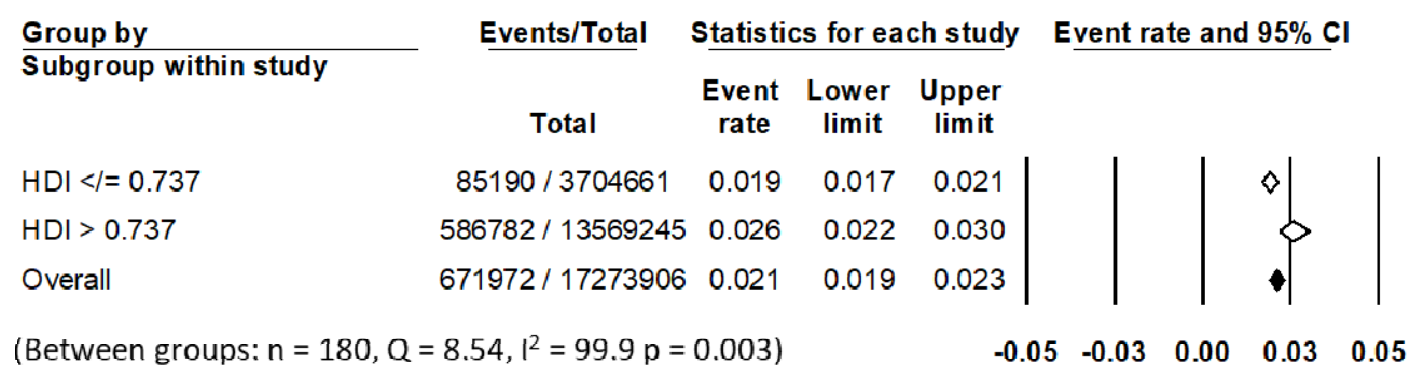

\section{(e) Group: Cancer Incldence}

Group by
Subgroup within study
$\mathrm{Ca}</=15726$
$\mathrm{Ca}>15726$
Overall

\section{Events/Total}

Total

$\begin{array}{cc}12332 / 817736 & 0.018 \\ 658028 / 16421140 & 0.026 \\ 670360 / 17238876 & 0.022\end{array}$

$670360 / 172388760.022$

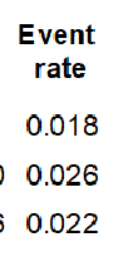

\section{Event rate and $95 \% \mathrm{Cl}$}

Lower Upper limit limit

$0.014 \quad 0.022$ 0.0220 .031 0.020

(Between groups: $n=178, Q=8.91,1^{2}=99.9 p=0.003$ )

$$
\begin{array}{lllll}
-0.05 & -0.03 & 0.00 & 0.03 & 0.05
\end{array}
$$

\section{(f) Group: Malarla Incldence}

\begin{tabular}{|c|c|c|c|c|c|c|}
\hline \multirow{2}{*}{$\begin{array}{l}\text { Group by } \\
\text { Subgroup within study }\end{array}$} & Events/Total & \multirow[b]{2}{*}{$\begin{array}{c}\text { Event } \\
\text { rate }\end{array}$} & \multirow[b]{2}{*}{$\begin{array}{l}\text { Lower } \\
\text { limit }\end{array}$} & \multirow[b]{2}{*}{$\begin{array}{c}\text { Upper } \\
\text { limit }\end{array}$} & \multicolumn{2}{|c|}{ Event rate and $95 \% \mathrm{C}$} \\
\hline & Total & & & & & \\
\hline Malaria $</=5.12 / 1000$ & $241681 / 6721681$ & 0.019 & 0.016 & 0.023 & & $\diamond$ \\
\hline Malaria > 5.12/1000 & $52141 / 2233615$ & 0.021 & 0.018 & 0.024 & & 8 \\
\hline Overall & 293822 / 8955296 & 0.020 & 0.018 & 0.023 & & $\bullet$ \\
\hline (Between groups: $n=1$ & $=0.46, \mathrm{I}^{2}=99.9 \mathrm{p}$ & : ns) & & -0.05 & $\begin{array}{ll}-0.03 & 0.00\end{array}$ & 0.03 \\
\hline
\end{tabular}

\section{(g) Group: Hypertensive heart disease (HHD)}

Group by

Subgroup within study

$\mathrm{HHD}</=56.26 / 100,000$

$\mathrm{HHD}>56.26 / 100,000$

Overall

\section{Events/Total Statistics for each study Event rate and $95 \% \mathrm{Cl}$}

Event Lower Upper

rate limit limit

$\begin{array}{llll}173115 / 4507919 & 0.021 & 0.017 & 0.025\end{array}$ $\begin{array}{lllll}498638 / 12769840 & 0.023 & 0.020 & 0.027\end{array}$ $\begin{array}{lllll}671753 / 17277759 & 0.022 & 0.020 & 0.025\end{array}$

(Between groups: $n=182 \mathrm{Q}=0.74, \mathrm{I}^{2}=99.9 \mathrm{p}: \mathrm{ns}$ ) 
medRxiv preprint doi: https://doi.org/10.1101/2020.08.12.20173617; this version posted August 14, 2020. The copyright holder for this preprint (which was not certified by peer review) is the author/funder, who has granted medRxiv a license to display the preprint in perpetuity.

All rights reserved. No reuse allowed without permission.

(h) Group: Dlabetes

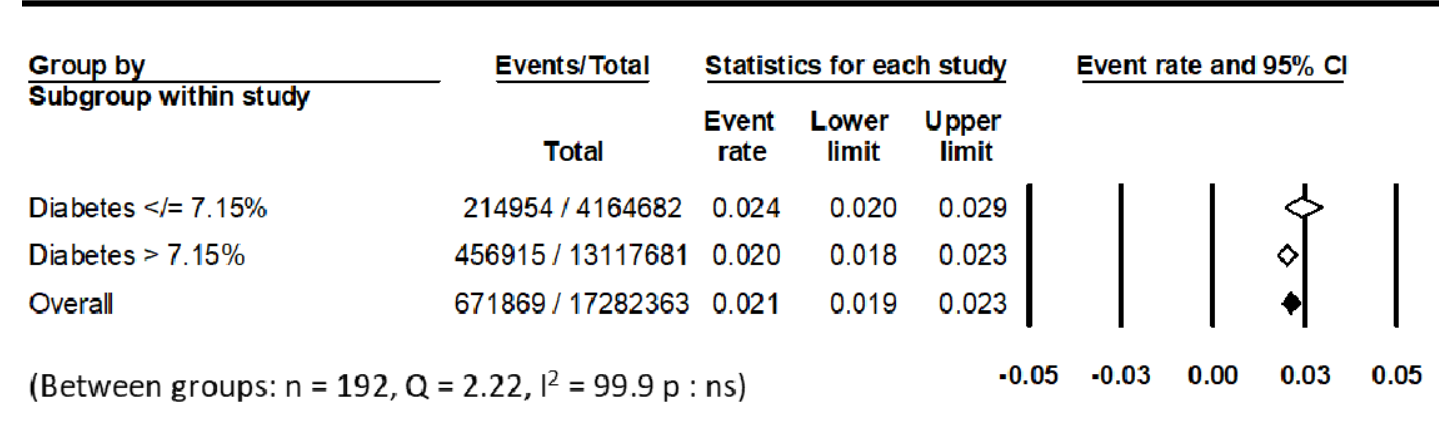

\section{(I) Group: Populatlon density}

\begin{tabular}{|c|c|c|c|c|c|c|c|c|}
\hline \multirow{2}{*}{$\frac{\text { Group by }}{\text { Subgroup within study }}$} & \multirow{2}{*}{$\begin{array}{c}\text { Events/Total } \\
\text { Total }\end{array}$} & \multicolumn{3}{|c|}{ Statistics for each study } & \multicolumn{4}{|c|}{ Event rate and $95 \% \mathrm{Cl}$} \\
\hline & & $\begin{array}{l}\text { Event } \\
\text { rate }\end{array}$ & $\begin{array}{l}\text { Lower } \\
\text { limit }\end{array}$ & $\begin{array}{l}\text { Upper } \\
\text { limit }\end{array}$ & & & & \\
\hline Pop Den $</=90.3 / \mathrm{sq} \mathrm{km}$ & $420325 / 12027706$ & 0.024 & 0.021 & 0.027 & & & $\hat{\gamma}$ & \\
\hline Pop Den > 90.3/sq km & $251256 / 5243605$ & 0.021 & 0.017 & 0.025 & & & $\theta$ & \\
\hline Overall & $671581 / 17271311$ & 0.023 & 0.021 & 0.026 & & & & \\
\hline (Between groups: $n=1$ & $=1.73, \mathrm{I}^{2}=99.9 \mathrm{p}:$ & ns) & & -0.0 & $5-0.03$ & 0.00 & 0.03 & 0.05 \\
\hline
\end{tabular}


Fig. 4 Impact of the none/ suspended vs. ongoing BCG vaccination programme on the COVID-19 case mortality rates for the high risk population (a) \% Population aged $65+$ years $(>7.1 \%)$ (b) Ischemic heart disease $/ 10^{5}$ population $\left(>1171 / 10^{5}\right)$ (c) Human development index (>0.737) and (d) Cancer incidence (> 56.25)

\section{(a) \% population aged $65+$ years $>7.1 \%$}

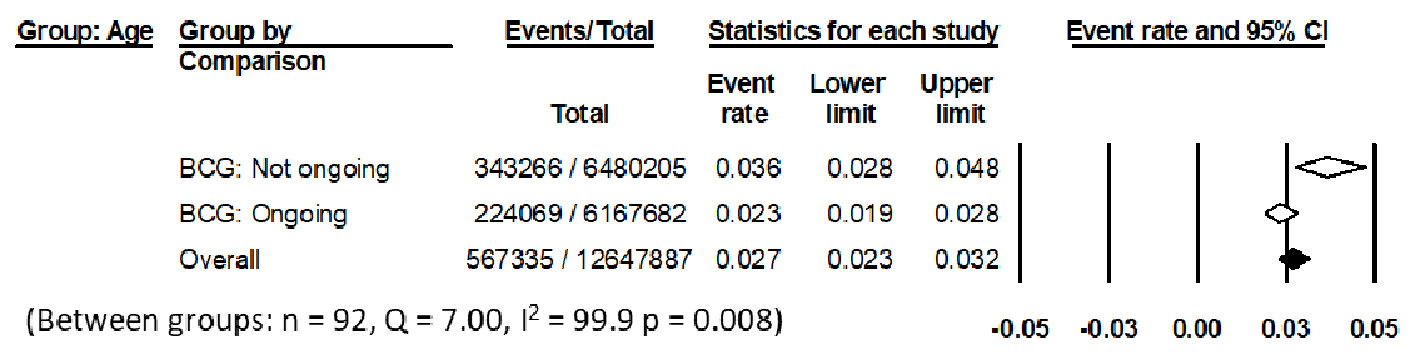

\section{(b) Ischemlc heart dlsease $>1171 / 10^{5}$ populatlon}

\begin{tabular}{|c|c|c|c|c|c|c|c|c|}
\hline Group: IHD & Group by & Events/Total & Statisti & s for ear & h study & Event $\mathbf{r}$ & te anc & $95 \% \mathrm{Cl}$ \\
\hline & Comparison & Total & $\begin{array}{c}\text { Event } \\
\text { rate }\end{array}$ & $\begin{array}{c}\text { Lower } \\
\text { limit }\end{array}$ & $\begin{array}{c}\text { Upper } \\
\text { limit }\end{array}$ & & & \\
\hline & BCG: Not ongoing & $343476 / 6524899$ & 0.035 & 0.026 & 0.045 & & & \\
\hline & BCG: Ongoing & $201400 / 6921346$ & 0.022 & 0.020 & 0.025 & & & $ه$ \\
\hline & Overall & $544876 / 13446245$ & 0.024 & 0.021 & 0.027 & & & \\
\hline (Between & groups: $\mathrm{n}=91$, & $20,1-99.50$ & $0.004)$ & & & -0.03 & 0.00 & 0.03 \\
\hline
\end{tabular}

\section{(c) Human development Index $>0.737$}

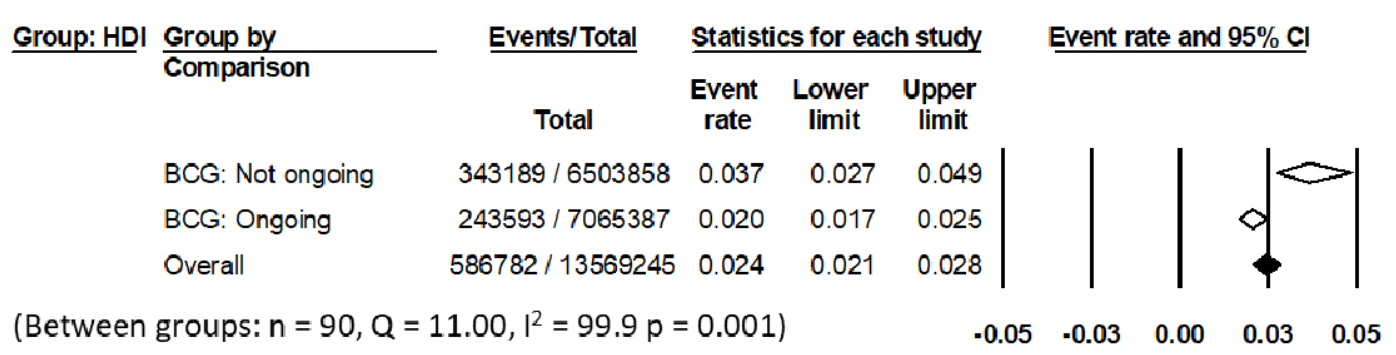


medRxiv preprint doi: https://doi.org/10.1101/2020.08.12.20173617; this version posted August 14, 2020. The copyright holder for this preprint (which was not certified by peer review) is the author/funder, who has granted medRxiv a license to display the preprint in perpetuity.

All rights reserved. No reuse allowed without permission.

\section{(d) Cancer Incldence > 15726}

\begin{tabular}{|c|c|c|c|c|c|c|c|c|c|}
\hline \multirow[t]{5}{*}{ Group: Cancer } & \multirow{2}{*}{$\frac{\text { Group by }}{\text { Comparison }}$} & \multirow{2}{*}{$\begin{array}{c}\text { Events/Total } \\
\text { Total }\end{array}$} & \multicolumn{3}{|c|}{ Statistics for each study } & \multicolumn{4}{|c|}{ Event rate and $95 \% \mathrm{Cl}$} \\
\hline & & & $\begin{array}{l}\text { Event } \\
\text { rate }\end{array}$ & $\begin{array}{l}\text { Lower } \\
\text { limit }\end{array}$ & $\begin{array}{l}\text { Upper } \\
\text { limit }\end{array}$ & & & & \\
\hline & BCG: Not ongoing & $342959 / 6469581$ & 0.043 & 0.031 & 0.059 & & & & \\
\hline & BCG: Ongoing & $315069 / 9951559$ & 0.022 & 0.018 & 0.025 & & & d & \\
\hline & Overall & $658028 / 16421140$ & 0.025 & 0.021 & 0.028 & & & & \\
\hline (Between gr & ups: $\mathrm{n}=89, \mathrm{Q}=$ & $8,1^{2}=99.9 p<0.0$ & 001) & & -0.05 & -0.03 & 0.00 & 0.03 & 0.05 \\
\hline
\end{tabular}


medRxiv preprint doi: https://doi.org/10.1101/2020.08.12.20173617; this version posted August 14, 2020. The copyright holder for this preprint (which was not certified by peer review) is the author/funder, who has granted medRxiv a license to display the preprint in perpetuity.

All rights reserved. No reuse allowed without permission.

Fig. 5 Impact of BCG strains on the COVID-19 case fatality rates in countries with ongoing BCG vaccination. This represent 127 of the 144 countries for which the BCG vaccination strains were available.

\section{Event rate vs. BCG stralns used for BCG vaccination}

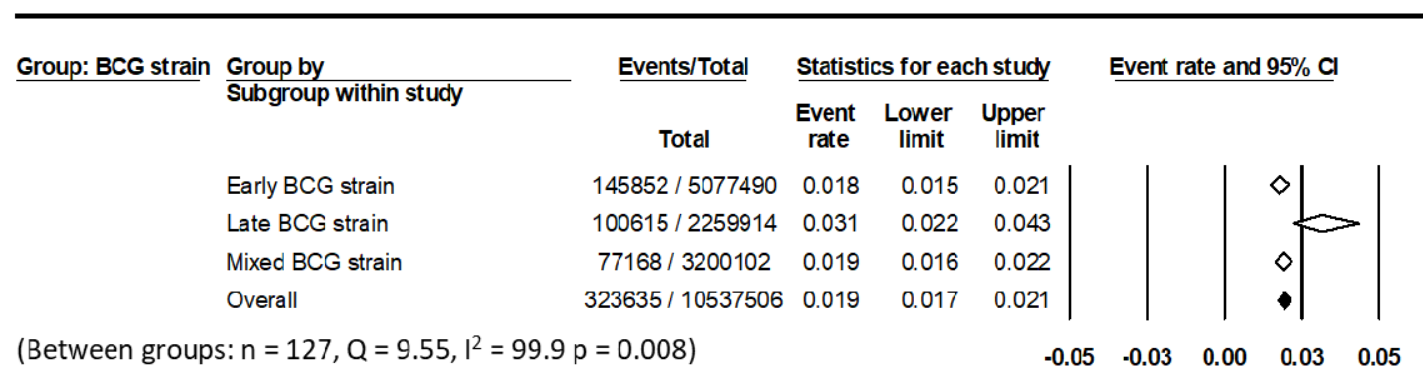

